\title{
Wpływ zailenia na wartości parametrów sprężystych w osadach miocenu
}

\section{The impact of shale volume on the elastic properties values in the Miocene deposits}

\author{
Anita Lis-Śledziona, Maja Mroczkowska-Szerszeń \\ Instytut Nafty i Gazu - Państwowy Instytut Badawczy
}

\begin{abstract}
STRESZCZENIE: Parametry sprężyste minerałów ilastych są słabo rozpoznane głównie z powodu niewielkich rozmiarów ziaren tych minerałów i trudności w wyizolowaniu pojedynczych kryształów tak, aby pomierzyć ich własności akustyczne. Do tej pory własności sprężyste minerałów ilastych określano za pomocą obliczeń teoretycznych lub przez połączenie wyników badań eksperymentalnych i obliczeń teoretycznych. Celem artykułu było określenie wpływu zawartości minerałów ilastych na wartości prędkości fali P oraz fali S. Jak wiadomo, wartości parametrów sprężystych ściśle zależą od porowatości. Jednak niebagatelny wpływ na te wartości ma także zawartość minerałów ilastych. W badanym ośrodku do głównych minerałów ilastych zaliczamy: illit (25-30\%), minerały mieszanopakietowe illit/smektyt (5-10\%) oraz kaolinit (0,5-1,3\%). Występują także krzemiany warstwowe w postaci chlorytu (2-9\%). Pierwszym etapem pracy było przeprowadzenie badań laboratoryjnych na dziewięciu próbkach pochodzących z osadów miocenu z profilu odwiertu R-1. Pomiary zawartości poszczególnych minerałów wykonano metodą spektroskopii w podczerwieni FTIR (Fourier-transform infrared spectroscopy) za pomocą przystawki ATR (attenuated total reflectance). Ponadto przeprowadzono pomiary prędkości fali $\mathrm{P}$ i fali S. Z uwagi na wysoką kruchość badanych próbek pomiary prędkości wykonano w warunkach statycznych. Na podstawie otrzymanych prędkości policzono wartości modułów sprężystości. W oparciu o pomierzone parametry zbudowano model mineralogiczny oraz wyliczono porowatość. Pomierzone statyczne wartości prędkości fal P i S przeliczono do wartości dynamicznych. Korzystając ze wzoru Castagny, obliczono wartości prędkości fali S. Finalnym etapem pracy było określenie zależności pomiędzy zawartością minerałów ilastych a wartościami prędkości fali $\mathrm{P}$, prędkością fali $\mathrm{S}$ oraz modułami sprężystości: modułem Younga i modułem sprężystości objętościowej. Przedstawiono także zależność prędkości fali P od wartości prędkości fali S dla różnych zakresów zawartości materii ilastej przy wykorzystaniu modelu Greenberga-Castagny dla utworów piaszczysto-ilastych.
\end{abstract}

Słowa kluczowe: moduły sprężystości, minerały ilaste, prędkości fal sprężystych, utwory piaszczysto-ilaste miocenu.

ABSTRACT: The elastic parameters of clay minerals are poorly recognized mainly due to the small size of clay minerals and the difficulty in isolating individual crystals to measure their acoustic properties. So far the effective elastic properties of clays have been derived either by theoretical computation, or by a combination of theoretical and experimental investigations on clay mixtures. The aim of the article was to determine the effect of clay mineral content on the values of P-wave velocity and S-wave velocity. In the research area, the main clay minerals are: illite (25-30\%), interstratified clay minerals illite/smectite (5-10\%) and kaolinite $(0.5-1.3 \%)$. There are also silicates present in the formation in the form of chlorite $(2-9 \%)$. The first stage of the work consisted in laboratory tests on nine samples from Miocene deposits from the R-1 well. The FTIR (Fourier Transformed Infrared Spectroscopy) was used to measure the content of individual minerals using ATR (Attenuated Total Reflectace) technique. In addition, P- and S-waves velocity measurements were performed. Due to the high brittleness of the tested samples, the velocity measurements were performed under static conditions. The values of the elastic modulus were calculated based on measured velocities. The mineralogical model was built and calibrated based on the measured clay content and porosity was calculated. As is well known, the values of elastic parameters are closely related to the porosity. However, the content of clay minerals also has a considerable impact on the values of elastic parameters. Static values of P-wave and S-wave velocity were converted to dynamic values. Using the Castagna formula, the values of S-wave velocity were calculated. The final stage of the work consisted in determining the relationship between the clay mineral content and P-wave velocity values, S-wave velocity and elastic moduli: the Young modulus, the bulk modulus. The relationship between P-wave velocity and S-wave velocity for different ranges of clay content was presented using the Greenberg-Castagna model for clastic silicate rocks.

Key words: elastic moduli, clay minerals, velocity of elastic waves, sandy-shaly Miocene formation.

Autor do korespondencji: A. Lis-Śledziona, e-mail: anita.lis@inig.pl

Artykuł nadesłano do Redakcji: 26.07.2019 r. Zatwierdzono do druku: 20.12.2019 r. 


\section{Wprowadzenie}

Występowanie minerałów ilastych jest szeroko rozpowszechnione w skorupie ziemskiej. Minerały te obserwujemy zwłaszcza w skałach klastycznych: iłowcach, mułowcach, piaskowcach, choć w niewielkich ilościach są także obecne w formacjach węglanowych. Ich obecność wpływa znacząco na wartości parametrów sprężystych badanych skał. Dwie próbki piaskowca o tej samej zawartości minerałów ilastych mogą charakteryzować się różnymi wartościami parametrów sprężystych w związku z różnymi rodzajami minerałów ilastych, które w nich występują. Zatem właściwe określenie parametrów sprężystych minerałów ilastych ma kluczowe znaczenie dla zrozumienia rejestrowanych wartości (odpowiedzi) sond w formacjach piaszczysto-ilastych (Mondol et al., 2008). W opracowaniu badano wpływ zawartości: illitu, chlorytu oraz smektytu na wartości prędkości fal P i S. Zagadnienie określania wartości parametrów sprężystych było przedmiotem wielu publikacji, m.in. takich autorów jak: Woeber et al. (1963), Katahara (1996), Wang et al. (2001) oraz Bała (2017).

Analizę zmian prędkości fal P i S od zawartości minerałów ilastych przeprowadzono w odwiercie R-1 w obrębie utworów miocenu autochtonicznego. Odwiert ten położony jest w obrębie złoża, które w latach 2000-2001 rozpoznane zostało w utworach miocenu oraz w stropie jurajskiego podłoża (Zych i Smółka-Gnutek, 2014). Obszar złoża położony jest na terenie województwa podkarpackiego w brzeżnej partii nasunięcia karpacko-stebnickiego, pomiędzy Ropczycami a Rzeszowem. Skałę zbiornikową stanowią serie piaskowcowo-mułowcowe o wysokich porowatościach efektywnych, rzędu 9-12\%, i przepuszczalności od 1,1 do 5,95 mD. Celem pracy było określenie wpływu zailenia na prędkość rozchodzenia się fal P i S. W pracy wykorzystano profilowania geofizyki otworowej oraz wyniki wykonanych analiz laboratoryjnych.

\section{Badania próbek skał mioceńskich metodami spektroskopii FTIR ATR}

W ramach realizacji pracy wykonano pomiary zawartości poszczególnych minerałów dla 9 próbek pochodzących z interwału miocenu autochtonicznego odwiertu R-1. Badania wykonano metodą spektroskopii w podczerwieni FTIR.

Do analiz wykorzystano fourierowski spektrometr marki Thermo Electron Nicolet 6700, wyposażony w wydajne źródło typu ETC EverGlow, detektor podczerwieni średniej DLaTGS z oknem KBr oraz dzielnik wiązki XT-KBr. Użyto przystawki ATR Specac Quest wyposażonej w diamentowy kryształ pomiarowy charakteryzujący się wysokim stosunkiem sygnału do szumu. Badania prowadzone były w podczerwieni średniej
- w zakresie $450 \mathrm{~cm}^{-1}$ do $4000 \mathrm{~cm}^{-1}$. Dla każdej próbki wykonano 128 powtórzeń z rozdzielczością $4 \mathrm{~cm}^{-1}$. Do analiz dostarczono 9 próbek w postaci wstępnie zmielonej. W pomiarze wykorzystywano niewielką, ale reprezentatywną ilość próbki, rzędu dziesiątych części grama. Każda z dostarczonych próbek została starannie domielona przed samym pomiarem, w pierwszym etapie za pomocą młyna kulowego, a następnie w moździerzu agatowym. Proces ten zapewniał jej reprezentatywność, tak aby otrzymać frakcję w przybliżeniu odpowiadającą zakresowi poniżej $20 \mu \mathrm{m}$.

Dla każdej próbki uzyskano widmo FTIR, które poddane zostało analizie jakościowej oraz półilościowej. Do analizy półilościowej wykorzystano specjalistyczne oprogramowanie analityczne TQ Analyst v.8.5.2 firmy Thermo Electron, zawierające narzędzia do statystycznej/ilościowej obróbki wyników badań spektroskopowych, między innymi algorytmy obliczeniowe PLS (partial least squares) oraz PCR (principal component regression).

Metody spektroskopii w podczerwieni ułatwiają klasyfikację próbek skalnych, umożliwiając identyfikację najistotniejszych składników mineralnych w mieszance, zarówno jakościowo, jak i ilościowo, w niektórych przypadkach półilościowo (np. przy znacznej zawartości pirytu czy halitu). O obecności poszczególnych minerałów świadczą ich widma, a ściślej określone pasma drgań cząsteczek tworzących minerał oraz ich względne intensywności.

Podczas analizy wyników trudność interpretacyjną może stanowić fakt nakładania się pasm niektórych składników. Dlatego dla każdego ze składników próbowano wskazać tzw. pasma analityczne - typowe, najlepiej unikalne, dla poszczególnych minerałów, w miarę możliwości nienakładające się z innymi pasmami. Wszystkie analizowane próbki zawierają mniejsze lub większe ilości minerałów węglanowych, przede wszystkim w postaci kalcytu i dolomitu, ale także ankerytu (rys. 1, pasma z maksimum $728 \mathrm{~cm}^{-1}, 878 \mathrm{~cm}^{-1}$ oraz $1429 \mathrm{~cm}^{-1}$ - dla dolomitu, a $713 \mathrm{~cm}^{-1}, 872 \mathrm{~cm}^{-1}$ dla kalcytu) We wszystkich próbkach obecny jest również kwarc $\left(796-776 \mathrm{~cm}^{-1}\right)$ oraz krzemiany warstwowe, w tym minerały ilaste.

\section{Zawartość faz mineratów ilastych na przyktadzie montmorillonitu oraz illitu - analiza jakościowa oraz ilościowa}

W zakresie niskoczęstotliwościowym pasma pochodzące od illitu i smektytu bardzo często pokrywają się z pasmami innych krzemianów, co znacznie utrudnia ich ocenę. Dlatego dobrym rozwiązaniem w przypadku analizy tych minerałów jest obserwacja charakterystycznych pasm wysokoczęstotliwościowych, a dokładniej analiza drgań rozciągających grupy $\mathrm{OH}$ wody związanej ze strukturą oraz wody międzypakietowej. Pasma drgań OH (dla wody międzypakietowej) występują 
w zakresie około $3000-3700 \mathrm{~cm}^{-1}$, jest to więc szerokie pasmo, obecne w próbkach smektytu lub z przewagą smektytu oraz charakteryzujące się wielokrotnie większą szerokością połówkową niż pasmo drgań grupy $\mathrm{OH}$ związanej ze strukturą, najczęściej z atomami glinu. Położenie maksimum pasma grup związanych $\mathrm{OH}$ w widmie FTIR ATR z kryształem diamentowym to $3618 \mathrm{~cm}^{-1}$. Pik ten obecny jest również dla fazy illitowej, w muskowicie także w fazie illit-smektyt. Ma on wówczas większą wartość absorbancji niż pasma wody międzypakietowej 3000-3700 $\mathrm{cm}^{-1}$ (Madejova i Komadel, 2001).

Tabela 1 zawiera subiektywną jakościową ocenę zawartości poszczególnych minerałów $\mathrm{w}$ dostarczonych próbkach skalnych na podstawie obecności widocznych pasm, w tym pasm analitycznych, oraz ich względnych intensywności. Plusami

Tabela 1. Opis jakościowy widm FTIR ATR - wyszczególniono minerały jakościowo oznaczalne na podstawie analizy widma oraz jego pasm analitycznych

Table 1. Qualitative description of FTIR ATR spectra - minerals qualitatively detectable were specified on the basis of spectrum analysis and its analytical bands

\begin{tabular}{|c|c|c|c|c|}
\hline \multirow{2}{*}{ Nr próbki } & \multicolumn{4}{|c|}{$\begin{array}{c}\text { Minerały składowe ze wskazaniem na fazy dominujące } \\
\text { i rozpoznawalne w analizie jakościowej }\end{array}$} \\
\cline { 2 - 5 } & kwarc & kalcyt + dolomit & illit + muskowit & krzem \\
\hline \hline 8208 & $(+)$ & $(+++)$ & $(++++)$ & $(++++)$ \\
\hline 8209 & $(+++)$ & $(++)$ & $(++)$ & $(-)$ \\
\hline 8210 & $(+++)$ & $(+++)$ & $(+)$ & $(-)$ \\
\hline 8211 & $(++)$ & $(+)$ & $(+++)$ & $(+)$ \\
\hline 8212 & $(++)$ & $(+++)$ & $(++)$ & $(++)$ \\
\hline 8213 & $(+++)$ & $(++)$ & $(++)$ & $(+)$ \\
\hline 8214 & $(++)$ & $(+)$ & $(++)$ & $(++)$ \\
\hline 8215 & $(++)$ & $(++)$ & $(+++)$ & $(++)$ \\
\hline 8216 & $(+)$ & $(+)$ & $(++++)$ & \\
\hline
\end{tabular}

$(++++)$ faza bardzo wyraźnie widoczna; $(+++)$ faza dobrze rozpoznawalna jakościowo, $(++)$ faza rozpoznawalna jakościowo, $(+)$ faza widoczna w niewielkiej ilości, $(-)$ faza nieobecna $(++++)$ the phase is clearly visible; $(+++)$ phase well-recognized qualitatively,

$(++)$ qualitatively recognizable phase, $(+)$ phase visible in a small amount, $(-)$ absent phase oznaczono minerały, których obecność można potwierdzić w analizie jakościowej. Przypisanie poszczególnym minerałom tej samej liczby plusów nie oznacza zbliżonej zawartości procentowej dla różnych minerałów. Największa liczba plusów oznacza największą zawartość danego minerału w wyanej próbce.

Widma FTIR ATR wraz z opisami najistotniejszych pasm, tym pasm analitycznych, przedstawiono na rysunku 1 .

W tabeli 2 zamieszczono wyniki półilościowej analizy FTIR ATR bez uwzględnienia faz tlenków metali (poza zakresem pomiarowym).

Wyniki uzyskano z wykorzystaniem metody statystycznej PCR kalibrowanej wynikami XRD dla innych serii próbek okruchowych (łupków sylurskich) w liczbie 44 widm wraz z rentgenowskimi danymi ilościowymi.

Należy zaznaczyć, że nie jest to optymalna wersja tej metody. Najlepsze dokładności uzyskuje się, gdy można skorzystać z własnych danych kalibracyjnych dla analizowanej serii. W praktyce najkorzystniej jest, gdy dysponujemy także przynajmniej kilkoma próbkami walidacyjnymi pozwalającymi uwiarygodnić przeprowadzone badania dla dłuższej serii pomiarowej. Przez próbki walidacyjne rozumiemy takie, na których wykonano równocześnie badania ilościowe XRD oraz FTIR.

Natomiast dane przedstawione $\mathrm{w}$ tabeli 2 z pewnością pozwalają prawidłowo ocenić wzajemne proporcje poszczególnych faz mineralnych.

Składnikiem obecnym we wszystkich próbkach jest kwarc, w ilości od 21\% do 26\% wagowych. Wszystkie próbki zawierają również kalcyt oraz dolomit, przy czym suma składników

Tabela 2. Wyniki analizy półilościowej na podstawie analizy widm FTIR ATR metodą PCR kalibrowanej danymi XRD

Table 2. Results of the semi-quantitative analysis based on the analysis of FTIR ATR spectra by PCR method, calibrated with XRD data

\begin{tabular}{|c|c|c|c|c|c|c|c|c|c|c|c|c|c|c|}
\hline \multirow{2}{*}{$\begin{array}{c}\mathrm{Nr} \\
\text { próbki }\end{array}$} & $\mathbf{Q}$ & PI & Sk-K & \multirow{2}{*}{$\begin{array}{c}\text { SUMA } \\
(\mathbf{Q}+\mathbf{P I}+ \\
\text { Sk-K) }\end{array}$} & C & D & An & \multirow{2}{*}{$\begin{array}{c}\text { SUMA } \\
\text { węglany } \\
(\mathbf{C}+\mathbf{D}+\mathbf{A n})\end{array}$} & $\mathbf{P}$ & $\mathbf{M}+\mathbf{I}$ & $\mathbf{I} / \mathbf{S}$ & Ch & Kl & \multirow{2}{*}{$\begin{array}{c}\text { SUMA } \\
\text { krzem } \\
\text { warstw. }\end{array}$} \\
\hline & [wp] & [wp] & [wp] & & [wp] & [wp] & [wp] & & [wp] & [wp] & [wp] & [wp] & [wp] & \\
\hline 8208 & 22,9 & 7,2 & 3,0 & 33,1 & 11,0 & 7,7 & 2,6 & 21,3 & 2,5 & 28,9 & 8,9 & 5,0 & 0,7 & 43,5 \\
\hline 8209 & 25,9 & 6,9 & 3,4 & 36,2 & 7,7 & 6,4 & 1,9 & 16,0 & 2,9 & 28,1 & 11,4 & 1,6 & 1,3 & 42,3 \\
\hline 8210 & 23,3 & 8,2 & 3,5 & 35,0 & 8,3 & 8,2 & 2,5 & 19,0 & 1,0 & 27,5 & 11,7 & 2,6 & 1,2 & 43,0 \\
\hline 8211 & 24,5 & 5,8 & 3,3 & 33,6 & 6,7 & 4,6 & 2,4 & 13,7 & 3,4 & 32,7 & 8,3 & 5,3 & 1,0 & 47,2 \\
\hline 8212 & 23,7 & 7,0 & 3,4 & 34,0 & 9,1 & 6,4 & 1,6 & 17,1 & 2,8 & 28,0 & 11,2 & 3,6 & 1,0 & 43,9 \\
\hline 8213 & 24,9 & 6,8 & 3,4 & 35,0 & 8,5 & 6,1 & 2,1 & 16,7 & 2,4 & 29,6 & 10,6 & 2,2 & 1,3 & 43,7 \\
\hline 8214 & 24,4 & 6,3 & 3,4 & 34,0 & 7,6 & 5,1 & 1,7 & 14,4 & 3,3 & 30,6 & 10,0 & 4,2 & 1,0 & 45,8 \\
\hline 8215 & 25,0 & 6,5 & 3,3 & 34,8 & 7,3 & 5,7 & 1,8 & 14,9 & 3,4 & 29,8 & 9,9 & 4,0 & 1,1 & 44,7 \\
\hline 8216 & 21,5 & 6,0 & 2,8 & 30,3 & 8,5 & 4,2 & 2,1 & 14,7 & 3,1 & 36,0 & 5,9 & 9,0 & 0,6 & 51,5 \\
\hline
\end{tabular}




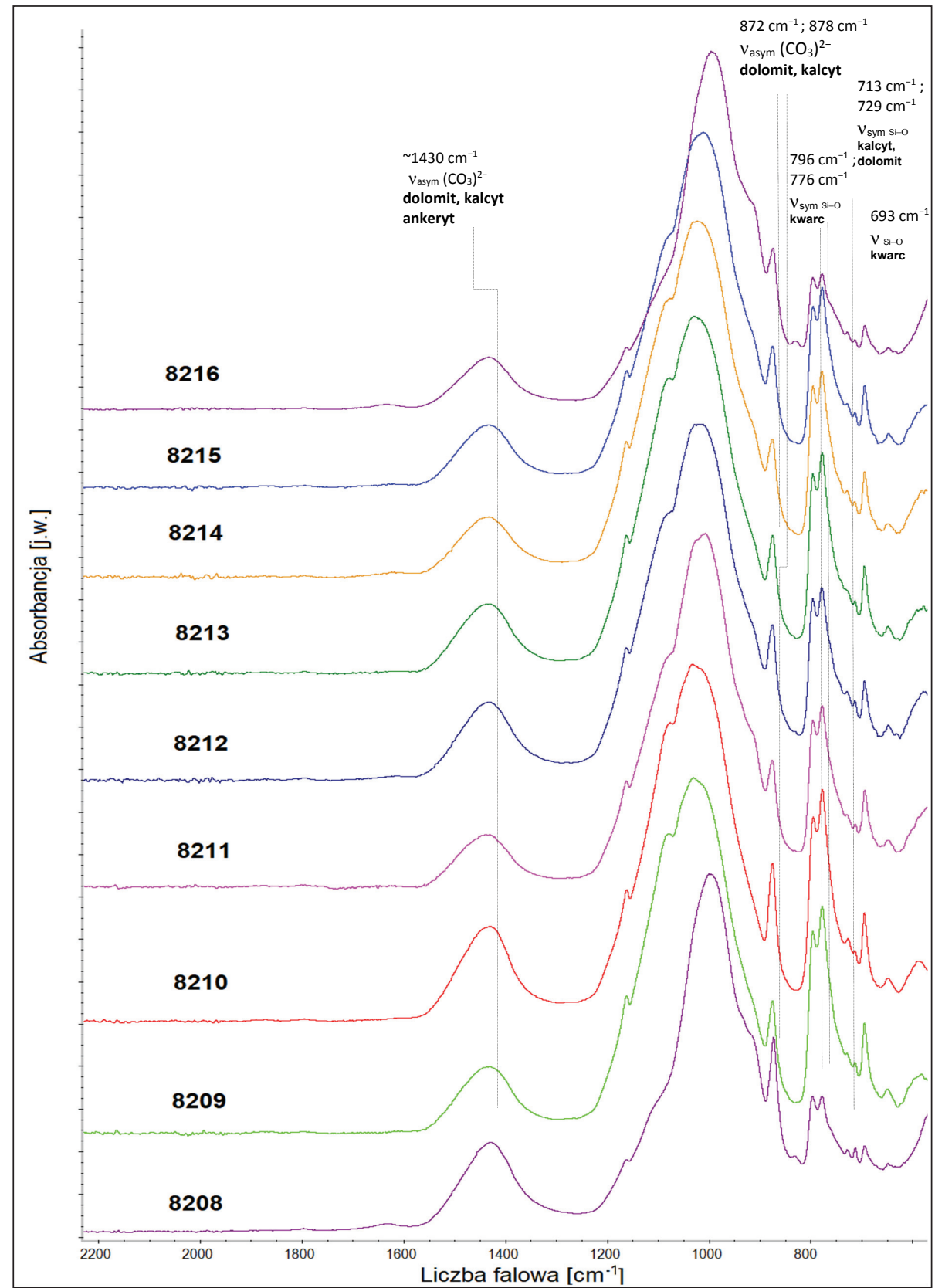

Rys. 1. Widma FTIR ATR (diamentowy) dla próbek 8208-8216 wraz z oznaczeniami wybranych pasm analitycznych przedstawione w zakresie pomiarowym od $550 \mathrm{~cm}^{-1}$ do $2250 \mathrm{~cm}^{-1}$; dla przejrzystości widma przedstawiono $\mathrm{w}$ przesunięciu, jedno nad drugim

Fig. 1. FTIR ATR (diamond) spectra for samples 8208-8216 with the selected analytical bands marked. The measurement range from $550 \mathrm{~cm}^{-1}$ to $2250 \mathrm{~cm}^{-1}$. The spectra shifted one above the other for clarity węglanowych waha się w granicach od niecałych $14 \%$ do $21 \%$. Wreszcie całkowita zawartość krzemianów warstwowych, faz: illit/smektyt, muskowit + illit, chlorytów oraz kaolinitu, pozostaje w zakresie między $42 \%$ a $51 \%$.

\section{Badania prędkości fal S i P oraz parametrów sprężystych}

Prędkości fal P i S zostały pomierzone na ośmiu rdzenikach o średnicy $2,5 \mathrm{~cm}$ i długości $3,5 \mathrm{~cm}$. Pierwotna idea zakładała pomiar w komorze ciśnieniowej w symulowanych warunkach złożowych, jednak z uwagi na znaczną porowatość i kruchość badanych próbek pomiary wykonano bez komory ciśnieniowej (próbki pękały) - wyniki przedstawiono w tabeli 3. Jedną z próbek udało się pomierzyć w symulowanych warunkach złożowych - wyniki prezentuje tabela 4. Pomiar wykonano zestawem P\&S Ultrasonic Velocity System ULT-100, firmy GCTS (USA). Aparatura pomiarowa składa się z generatora fal sprężystych oraz czujników, posiadających płytki testowe z wbudowanymi kryształkami piezoelektrycznymi, częstotliwość własna drgań czujników wynosiła 200 kHz. Zestaw umożliwia rejestrację pełnych obrazów falowych fal P i S oraz wyliczenie dynamicznych modułów sprężystych w warunkach ciśnienia atmosferycznego. Rejestracja przebiegu fal i zapis wyników pomiarów odbywa się przy wykorzystaniu specjalistycznego oprogramowania GCTS Ultrasonic Velocity (Puskarczyk et al., 2017). 
Tabela 3. Pomiary wykonane w warunkach powierzchniowych $\mathrm{w}$ temperaturze $24^{\circ} \mathrm{C}$ i pod ciśnieniem 3 bar

Table 3. Measurements carried out at a temperature of 24 degrees Celsius and a pressure of 3 bar

\begin{tabular}{|c|c|c|c|c|c|c|c|}
\hline \multirow{2}{*}{ Nr próbki } & $\begin{array}{l}\text { Prędkość } \\
\text { fali } \mathrm{P}, V_{p}\end{array}$ & $\begin{array}{l}\text { Prędkośćc } \\
\text { fali } \mathrm{S}, V_{s}\end{array}$ & \multirow{2}{*}{$\begin{array}{c}\text { Stosunek } \\
\text { fali P do fali S }\end{array}$} & \multirow{2}{*}{$\begin{array}{l}\text { Współczynnik } \\
\text { Poissona (v) }\end{array}$} & $\begin{array}{c}\text { Modul } \\
\text { Younga }(E)\end{array}$ & $\begin{array}{c}\text { Moduł sprężystości } \\
\text { objętościowej }(K)\end{array}$ & $\begin{array}{c}\text { Modul } \\
\text { ścinania }(G)\end{array}$ \\
\hline & {$[\mathrm{m} / \mathbf{s}]$} & {$[\mathrm{m} / \mathrm{s}]$} & & & [GPa] & [GPa] & [GPa] \\
\hline 8209 & 1555 & 656 & 2,37 & 0,39 & 2,41 & 3,71 & 0,87 \\
\hline 8210 & 2119 & 1071 & 1,98 & 0,33 & 6,63 & 6,44 & 2,49 \\
\hline 8211 & 1458 & 827 & 1,76 & 0,26 & 3,52 & 2,47 & 1,39 \\
\hline 8212 & 1595 & 821 & 1,94 & 0,32 & 3,70 & 3,43 & 1,40 \\
\hline 8213 & 1305 & 723 & 1,80 & 0,28 & 2,69 & 2,03 & 1,05 \\
\hline 8214 & 1029 & 571 & 1,80 & 0,28 & 1,61 & 1,21 & 0,63 \\
\hline 8215 & 1445 & 812 & 1,78 & 0,27 & 3,52 & 2,54 & 1,39 \\
\hline 8216 & 1702 & 830 & 2,05 & 0,34 & 3,76 & 4,02 & 1,40 \\
\hline
\end{tabular}

Tabela 4. Pomiar w komorze trójosiowej przy symulacji warunków ciśnienia złożowego i temperatury

Table 4. Measurement in a three-axis chamber in the reservoir conditions (pressure and temperature)

\begin{tabular}{|c|c|c|c|c|c|c|c|}
\hline \multirow[t]{2}{*}{ Nr próbki } & $\begin{array}{l}\text { Prędkość } \\
\text { fali } \mathrm{P}, V_{p}\end{array}$ & $\begin{array}{l}\text { Prędkość } \\
\text { fali S, } V_{s}\end{array}$ & \multirow{2}{*}{$\begin{array}{c}\text { Stosunek } \\
\text { prędkości } \\
\text { fali P do fali S }\end{array}$} & \multirow{2}{*}{$\begin{array}{l}\text { Współczynnik } \\
\text { Poissona (v) }\end{array}$} & $\begin{array}{c}\text { Modul } \\
\text { Younga }(E)\end{array}$ & $\begin{array}{c}\text { Modul sprężystości } \\
\text { objętościowej }(K)\end{array}$ & $\begin{array}{c}\text { Modul } \\
\text { ścinania }(G)\end{array}$ \\
\hline & {$[\mathbf{m} / \mathbf{s}]$} & {$[\mathrm{m} / \mathrm{s}]$} & & & [GPa] & [GPa] & [GPa] \\
\hline 8211 & 2506 & 1459 & 1,72 & 0,24 & 15,93 & 7,02 & 4,34 \\
\hline
\end{tabular}

\section{Opracowanie modelu petrofizycznego badanego odwiertu}

Wyniki analiz spektrometrycznych FTIR ATR posłużyły do kalibracji modelu petrofizycznego badanego odwiertu. Analizę przeprowadzono w aplikacji Quanti.Elan, opartej na algorytmach optymalizacyjnych. Jako dane wejściowe wykorzystano pomiary geofizyki wiertniczej: pomiar naturalnej promieniotwórczości gamma ray (GR), profilowanie porowatości neutronowej (NPHI), gęstość objętościową (RHOB), profilowanie akustyczne czasu interwałowego (DT), oporność strefy dalekiego zasięgu (RT) oraz wyniki analiz laboratoryjnych.
Rysunek 2 przedstawia przyjęte wartości parametrów petrofizycznych dla poszczególnych minerałów. Przyjęto model petrofizyczny zbudowany z sześciu składników mineralnych oraz porowatości. Zawartości poszczególnych minerałów zostały skorelowane z wynikami profilowań geofizyki wiertniczej i wprowadzone do modelu jako tzw. constraint tool w celu kalibracji wyników. Zawartość TOC (total organic carbon) została obliczona metodą Bowmana (2010) oraz przeliczona na objętościową zawartość kerogenu i wprowadzona do modelu.

$$
\begin{aligned}
& \text { ILLIT + SMEKTYT + CHLORYT + KWARC + } \\
& + \text { WĘGLANY + KEROGEN + POROWATOŚĆ }
\end{aligned}
$$

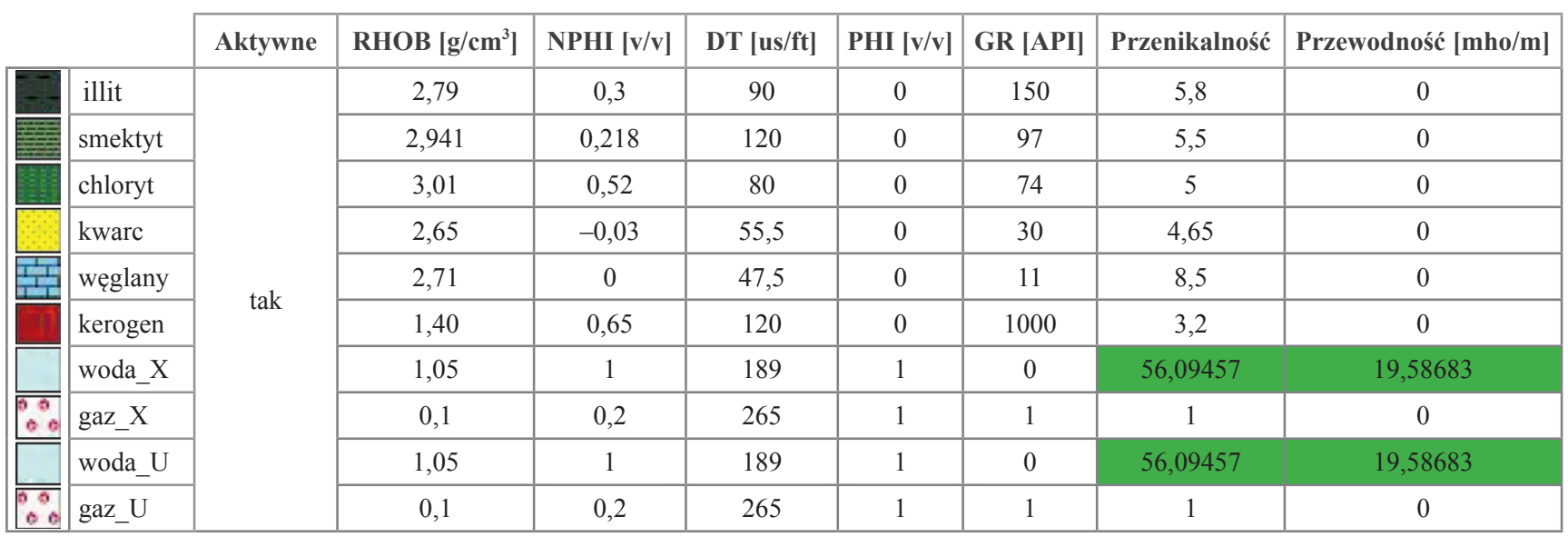

Rys. 2. Wartości parametrów petrofizycznych przypisanych poszczególnym minerałom

Fig. 2. The values of petrophysical parameters assigned to particular minerals 


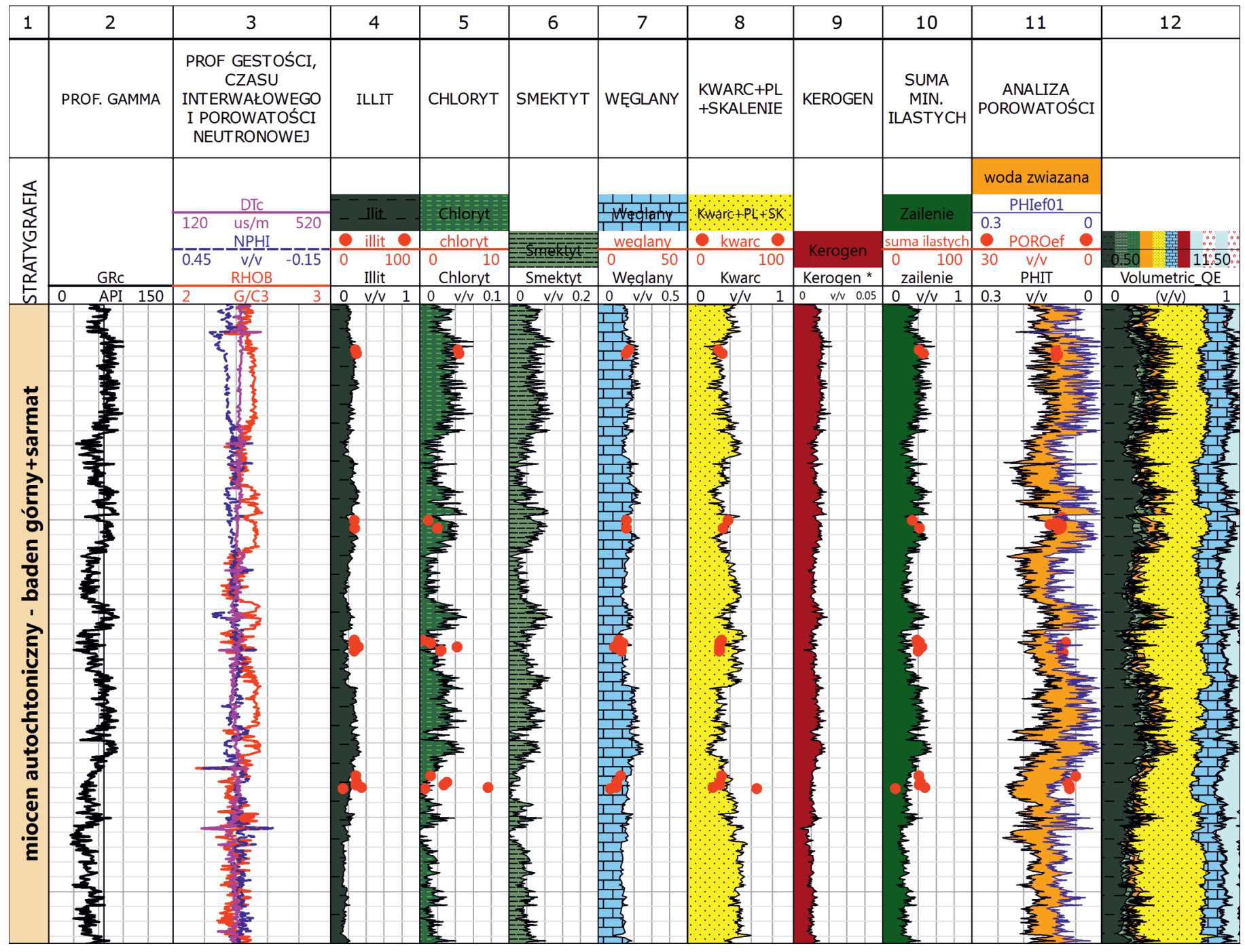

Rys. 3. Analiza zawartości poszczególnych składników mineralnych oraz porowatości w zestawieniu z wynikami pomiarów laboratoryjnych Fig. 3. The volumes of individual minerals and porosity and the results of laboratory measurements of mineral contents (red dots)

Wyznaczone, skalibrowane z wynikami badań laboratoryjnych zawartości minerałów ilastych (illitu, smektytu oraz chlorytu) przedstawiono na rysunku 3, w kolumnach 4-6. Kolumny 7-10 przedstawiają kolejno objętościową zawartość węglanów $(\mathrm{C}+\mathrm{D})$, kwarcu $(\mathrm{Q}+\mathrm{PL}+\mathrm{Sk})$, kerogenu oraz sumaryczną objętość minerałów ilastych. W kolumnie 11 zestawiono porowatość efektywną i całkowitą, natomiast w kolumnie 12 pełne rozwiązanie litologiczne odwiertu R-1.

\section{Analiza wpływu materiału ilastego na dynamiczne wartości parametrów sprężystych}

W kolejnym etapie przeliczono pomierzone wartości statyczne parametrów sprężystych do wartości dynamicznych na podstawie zależności korelacyjnych przedstawionych w pracy Słoty-Valim (2015). Wartości dynamiczne powinny odzwierciedlać warunki panujące w złożu. W tabeli 5 przedstawiono wyliczone dynamiczne wartości parametrów sprężystych. Następnie wyznaczono wartości prędkości fali P na podstawie pomiarów czasu interwałowego (DT) w odwiercie, natomiast wartości fali $V_{s}$ wyliczono, korzystając z modelu teoretycznego Castagny et al. (1993):

model Castagny $V_{s}=0,8042 \cdot V_{p}-0,8559[\mathrm{~km} / \mathrm{s}]$

$\mathrm{W}$ oparciu o dane geofizyki wiertniczej wyliczono dynamiczne wartości paramtrów sprężystych. Natomiast pomierzone laboratorynie wartości prędkości oraz parametrów sprężystych przeliczono z wartości statycznych na dynamiczne. Uzyskane wyniki przestawione zostały na rysunku 4. Ponadto kolorem czerwonym wyróżniono także dynamiczne wartości parametrów sprężystych, które zdołano pomierzyć dla jednej z próbek (rys. 4). Pierwotnie wyliczone z równania Castagny wartości prędkości fali $\mathrm{S}\left(V_{s}\right)$ przeliczono na podstawie poniższego równania Greenberga-Castagny ( $V_{s}$ Modeled) (1), uwzględniającego objętościową zawartość frakcji ilastej, węglanów oraz kwarcu (Castagna el al., 1985). 


\section{NAFTA-GAZ}

Tabela 5. Dynamiczne wartości parametrów sprężystych

Table 5. Dynamic values of elastic parameters

\begin{tabular}{|c|c|c|c|c|c|c|c|}
\hline \multirow[t]{2}{*}{ Nr próbki } & $\begin{array}{l}\text { Prędkość } \\
\text { fali } \mathrm{P}, V_{p}\end{array}$ & $\begin{array}{l}\text { Prędkość } \\
\text { fali S, } V_{s}\end{array}$ & \multirow{2}{*}{$\begin{array}{c}\text { Stosunek } \\
\text { fali P do fali } S\end{array}$} & \multirow{2}{*}{$\begin{array}{l}\text { Współczynnik } \\
\text { Poissona (v) }\end{array}$} & $\begin{array}{c}\text { Modul } \\
\text { Younga }(E)\end{array}$ & $\begin{array}{c}\text { Moduł sprężystości } \\
\text { objętościowej }(K)\end{array}$ & $\begin{array}{c}\text { Modul } \\
\text { ścinania }(G)\end{array}$ \\
\hline & {$[\mathrm{m} / \mathbf{s}]$} & {$[\mathbf{m} / \mathbf{s}]$} & & & [GPa] & [GPA] & [GPa] \\
\hline 8209 & 3204,48 & 2229,35 & 1,44 & 0,40 & 29,02 & 8,81 & 12,03 \\
\hline 8210 & 3868,81 & 2616,47 & 1,48 & 0,35 & 39,42 & 13,71 & 16,07 \\
\hline 8211 & 3179,09 & 2351,32 & 1,35 & 0,29 & 31,76 & 6,59 & 13,32 \\
\hline 8212 & 3284,74 & 2348,65 & 1,40 & 0,34 & 32,20 & 8,31 & 13,35 \\
\hline 8213 & 3021,35 & 2252,95 & 1,34 & 0,31 & 29,71 & 5,80 & 12,48 \\
\hline 8214 & 2868,27 & 2191,82 & 1,31 & 0,31 & 27,05 & 4,33 & 11,43 \\
\hline 8215 & 3205,68 & 2364,90 & 1,36 & 0,30 & 31,76 & 6,72 & 13,32 \\
\hline 8216 & 3360,46 & 2355,57 & 1,43 & 0,36 & 32,35 & 9,37 & 13,35 \\
\hline
\end{tabular}

$$
\frac{\left(\sum \text { minerali } \frac{V f_{i}}{\left(a_{i} \cdot V_{p}^{2}+b_{i} \cdot V_{p}+c_{i}\right)}\right)^{-1}+\sum \text { minerali } V f_{i} \cdot\left(a_{i} \cdot V_{p}^{2}+b_{i} \cdot V_{p}+c_{i}\right)}{2}
$$

gdzie: $V_{p}$ i $V_{s}$-wyrażone w $\mathrm{km} / \mathrm{s}$, reprezentują prędkości fal $\mathrm{P}$ natomiast $V f_{i}$ - to objętościowe zawartości poszczególnych oraz $\mathrm{S}$ dla skały w pełni nasyconej solanką, $a_{i}, b_{i}, c_{i}$ - to współ- grup minerałów: węglanów, kwarcu i minerałów ilastych. czynniki wyznaczone dla poszczególnych typów minerałów, Największe różnice pomiędzy wartościami wyliczonymi

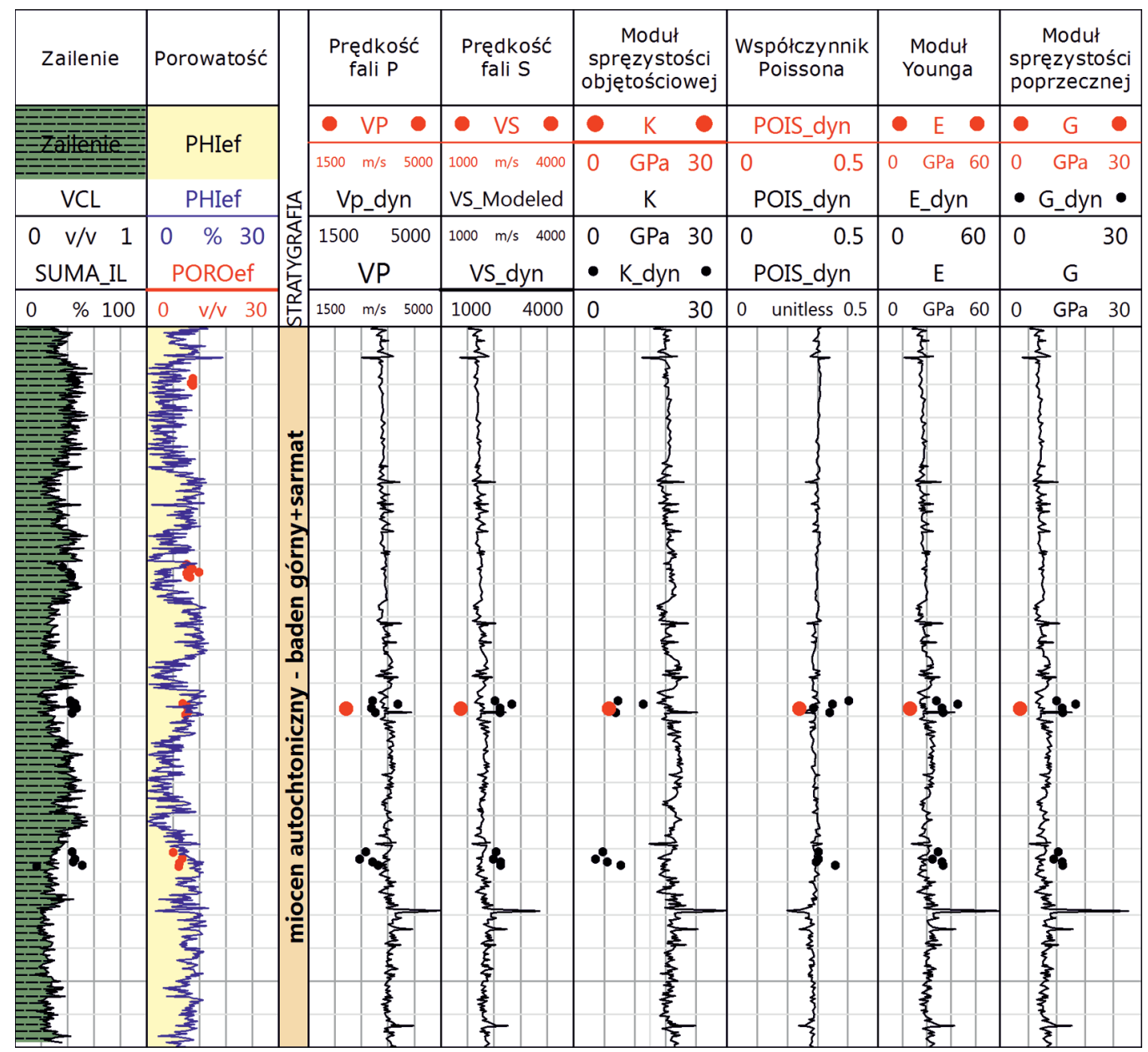

Rys. 4. Model zailenia i porowatości utworów miocenu w odwiercie R-1 zestawiony z dynamicznymi wartościami parametrów sprężystych

Fig. 4. Shale volume and porosity model for Miocene deposits in well R-1 and the values of dynamic elastic parameters 
z danych geofizyki wiertniczej a wartościami dynamicznych parametrów sprężystych, przeliczonych za pomocą korelacji pomierzonych laboratoryjnie wartości statycznych, obserwuje się dla modułu sprężystości objętościowej (K). (rys. 4). Różnice te wynikają najpewniej ze zjawiska dyspersji, związanego z różnicą częstotliwości podczas wykonywania pomiarów oraz różnicą pomiędzy naprężeniami działającymi na skałę w warunkach in situ oraz w warunkach laboratoryjnych. Wartości prędkości zarejestrowanych dla wysokich częstotliwości są generalnie wyższe, co bezpośrednio wpływa także na wartości parametrów sprężystych. Częstotliwości fal dla pomiarów otworowych wynoszą około $10 \mathrm{kHz}$, podczas pomiarów sejsmicznych operuje się częstotliwościami rzędu $10-50 \mathrm{~Hz}$, natomiast najniższe wartości częstotliwości obserwuje się podczas wykonywania osiowych testów ściskania w celu wyznaczenia statycznych parametrów sprężystych. Ponadto różnice w wartościach prędkości i parametrów sprężystych otrzymywanych z różnych metod pomiarowych wynikają także z odmiennych własności płynów nasycających skałę/rdzeń (Słota-Valim, 2015). Fala szybciej rozchodzi się w skale wypełnionej wodą złożową niż ropą czy gazem. Zwłaszcza obecność gazu silnie obniża prędkość rozchodzenia się fal. Korzystając z wyznaczonych i skalibrowanych z wynikami pomiarów laboratoryjnych zawartości minerałów ilastych: illitu, chlorytu oraz smektytu, wykonano analizę zależności objętościowych zawartości tych minerałów od wyliczonych na podstawie danych otworowych dynamicznych wartości parametrów sprężystych oraz od prędkości fal $V_{p} \mathrm{i} V_{s}$. Analiza zmienności została przeprowadzona na wyliczonych i skalibrowanych ciągłych krzywych, gdyż ilość pomierzonych laboratoryjnie danych była zbyt mała i korelacje oparte jedynie ma kilku danych punktowych nie dały wiarygodnych rezultatów. Przy analizie zmian prędkości w funkcji zailenia należy także uwzględnić wpływ porowatości - próbka o wyższej porowatości będzie charakteryzowała się niższą prędkością rozchodzenia się fal niż próbka o tej samej zawartości minerałów ilastych, lecz niższej porowatości. Analiza powinna zatem zostać przeprowadzona na zbiorach danych o zbliżonych porowatościach.

Spośród minerałów ilastych największą objętość stanowi illit, którego zawartość wynosi w granicach 10-35\%, smektyt stanowi natomiast zaledwie kilka procent objętości, maksymalnie do $11 \%$. Zauważamy generalnie spadek wartości prędkości fali P przy zwiększającym się udziale frakcji ilastej. Zmiany te rozpatrywane były w interwałach cechujących się różnymi zakresami wartości porowatości. W badanej formacji prędkość fali P zmienia się generalnie w zakresie $2500-4500 \mathrm{~m} / \mathrm{s}$. Rysunek 5 przedstawia wpływ zailenia na prędkość fali P dla utworów miocenu o porowatości $0-5 \%$. Jak wiadomo, porowatość ma obniżający wpływ na wartości

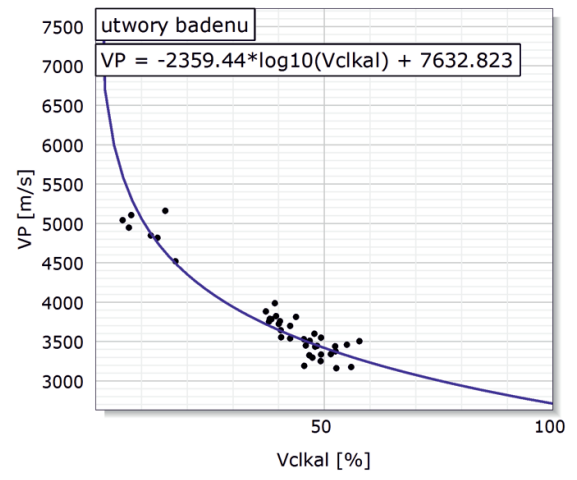

Rys. 5. Analiza zmian prędkości fali P dla interwałów o porowatości 0-5\% w utworach badenu

Fig. 5. Analysis of the P-wave velocity changes for the intervals with a porosity of $0-5 \%$ in Badenian deposits

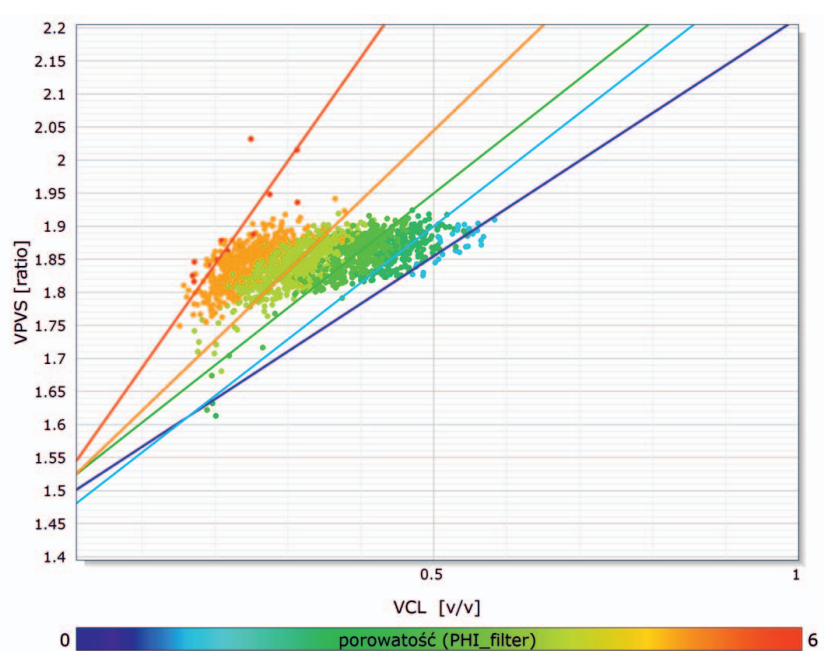

Rys. 6. Analiza zmian stosunku prędkości fali P do S od sumarycznej zawartości minerałów ilastych. Pięć poprowadzonych linii korelacyjnych przedstawia zależność VPVS od VCL dla osadów o różnej porowatośc

Fig. 6. Analysis of changes in the P-wave to S-wave velocity ratio from the shale volume. Five drawn correlation lines show relation between VPVS and VCL for rocks of different porosity

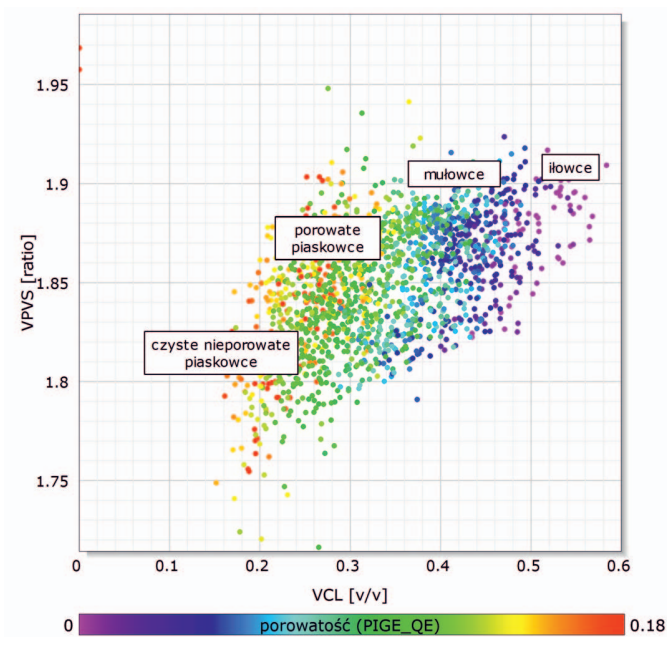

Rys. 7. Analiza zmian stosunku prędkości fali P do S od sumarycznej zawartości minerałów ilastych, dla różnych jednostek litologicznych

Fig. 7. Analysis of changes in the $\mathrm{P}$-wave $\mathrm{S}$-wave velocity ratio from the shale volume for different lithological units 
prędkości fal sprężystych, dlatego zależność badano dla interwałów o podobnej, niskiej porowatości. Osady miocenu wskazują na spadek prędkości fali P wraz ze wzrastającym udziałem frakcji ilastej.

Na rysunkach 6 i 7 widoczny jest znaczny wpływ sumarycznej ilości minerałów ilastych (zmieniających się w zakresie od $15 \%$ do 60\%) na stosunek prędkości fali $\mathrm{P}$ do prędkości fali S. Formacje podzielono na 5 grup o różnej porowatości efektywnej, kolor ciemnoniebieski odpowiada najniższym porowatościom, w zakresie $0-1 \%$, kolor niebieski: 1-5\%, kolor zielony to interwały o porowatości 5-10\%, kolor pomarańczowy odpowiada porowatościom 10-15\%, natomiast kolorem czerwonym oznaczone są najwyższe wartości porowatości - powyżej 15\%. Podobnie jak w pracy Zhu et al. (2001) zaobserwowano, że stosunek prędkości fal $V_{p} / V_{s}$ dla czystych, nieporowatych piaskowców wynosi 1,75-1,8, natomiast dla mułowców wartości $V_{p} / V_{s}$ wynoszą około 1,85-1,9. Nie zaobserwowano jednak tzw. krytycznej zawartości iłów. Marion et al. (1992) notują, iż przy wzroście zailenia powyżej około 40\% następuje spadek $V_{p} / V_{s}$ wraz ze wzrostem frakcji ilastej.

Wykorzystano również model Greenberga-Castagny dla utworów piaszczysto-ilastych przedstawiający zależność prędkości fali $\mathrm{P}$ od prędkości fali $\mathrm{S}$ dla różnych zakresów zawartości frakcji ilastej (rys. 8). Wartości prędkości fal P i S pozostają w ścisłym związku z zawartością frakcji ilastej; obserwujemy wprost proporcjonalne zmiany prędkości fali $\mathrm{P}$ do prędkości fali S dla czterech wydzielonych zakresów zawartości iłów: 0-25\%, 25-50\%, 50-75\% i 75-100\%. Podobną relację zmian zaobserwowano, analizując wartości prędkości fali S w zestawieniu z wartościami modułu Younga (E) (rys. 9) oraz z wartościami modułu sprężystości objętościowej $(K)$ (rys. 10). Dla różnych zakresów zawartości minerałów ilastych obserwuje

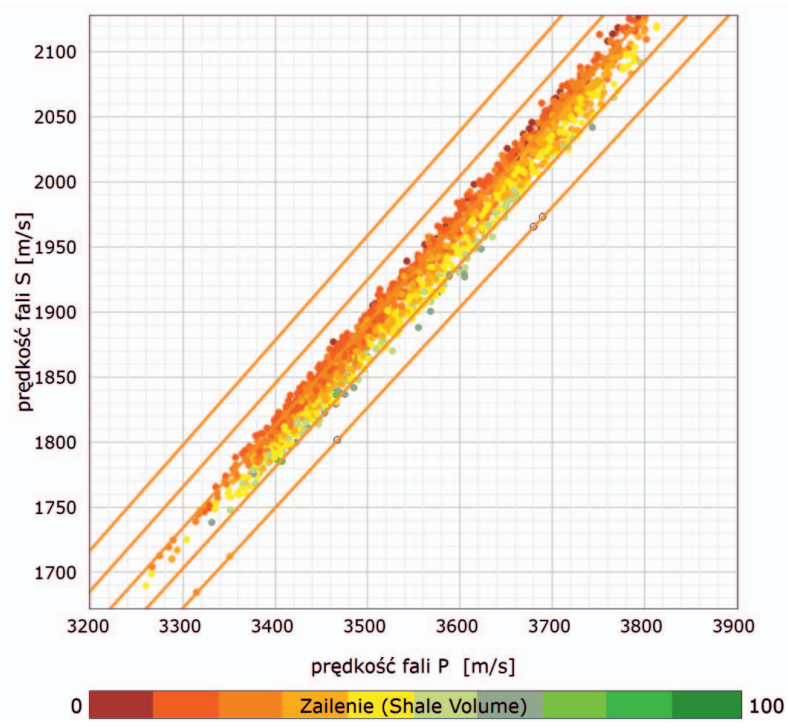

Rys. 8. Model Greenberga-Castagny dla utworów piaszczystoilastych

Fig. 8. Greenberg-Castagna model for shaly-sand formation

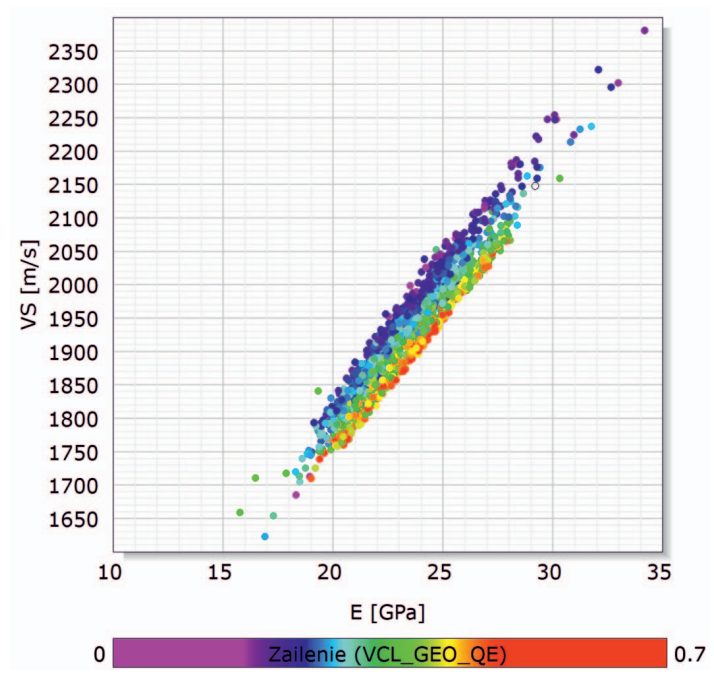

Rys. 9. Analiza zmian prędkości fali $\mathrm{S}$ w zależności od wartości modułu Younga dla różnych zakresów zawartości minerałów ilastych

Fig. 9. The analysis of changes in the $\mathrm{S}$ wave velocity versus on the Young's modulus for various ranges of shale volume

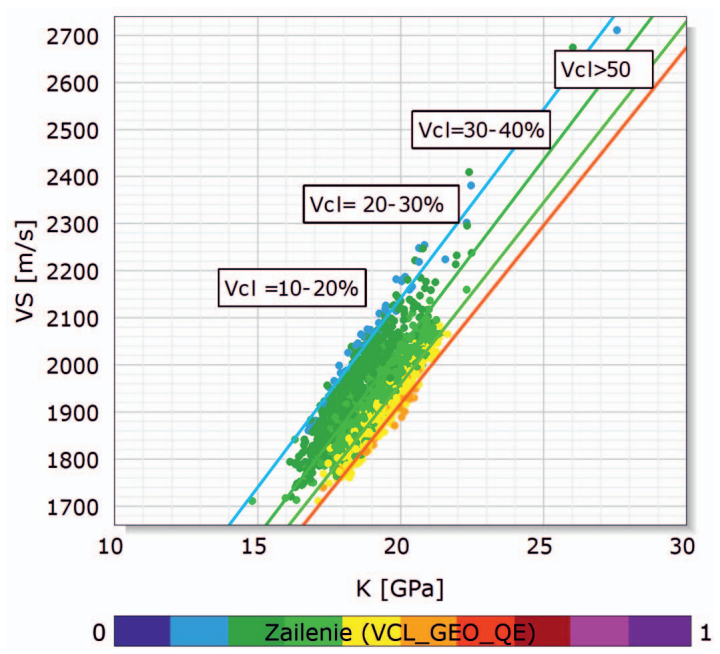

Rys. 10. Analiza zmian prędkości fali $\mathrm{S}$ w zależności od wartości modułu sprężystości objętościowej $(K)$

Fig. 10. The analysis of changes in the $\mathrm{S}$ wave velocity versus on the values of bulk modulus $(K)$

się proporcjonalną, liniową zależność prędkości fali $\mathrm{S}\left(V_{s}\right)$ od wartości modułu Younga $(E)$ i wartości modułu sprężystości objętościowej $(K)$. Na rysunku 10 przedstawiono 4 linie korelacyjne zależności $V_{s}$ od $K$, odpowiednio dla różnych zakresów zawartości materiału ilastego: $10-20 \%, 20-30 \%, 30-40 \%$ i powyżej 50\%. Wartości modułu sprężystości objętościowej generalnie zmieniają się w zakresie 16-23 GPa, natomiast w przypadku modułu Younga dominują wartości z zakresu 18-29 GPa. Prędkość fali S zmienia się w granicach 1700-2300 m/s.

Poniższy crossplot (rys. 11) wskazuje na zależność pomiędzy współczynnikiem Poissona a sumaryczną objętością minerałów ilastych. Przeprowadzono 5 linii korelacyjnych, odpowiednio dla zakresów porowatości: 0-1\% - linia ciemnoniebieska, 
$1-5 \%$ - linia niebieska, 5-10\% - linia ciemnozielona, $10-15 \%$ - linia jasnozielona, 15-20\% - linia pomarańczowa.

Dla ośrodków dwu- i więcej fazowych wprowadzono graniczne wartości modułów sprężystości, opisywane w literaturze jako granice Hashima-Shtrikmana lub uproszczone granice Voigta i Reussa. Górna granica - Voigta dla dowolnych modułów sprężystości efektywnego ośrodka skalnego złożonego z kilku składników przedstawia stosunek średnich wartości naprężeń do średnich wartości odkształceń, gdy wszystkie komponenty skalne odniesione są do tego samego odkształcenia (isostrain). Dolna granica - Reussa prezentuje stosunek średnich wartości naprężeń do średnich wartości odkształceń, gdy wszystkie wartości odpowiadają takim samym naprężeniom (isostress) (Mavko et al., 2003). Na rysunku 12 przedstawiono zależności prędkości fali P od porowatości dla różnych zakresów zawartości illitu, chlorytu i minerałów mieszanopakietowych illit/smektyt oraz zaznaczono przebieg granicy Voigta i Reussa dla modelu piaskowiec-woda. Granice te opisują związek porowatości z wartościami modułów sprężystości. Górna utożsamiana jest z modelem skał zbitych, zaś dolna - skał nieskonsolidowanych.

Można zauważyć liniowy spadek prędkości fali $\mathrm{P}$ dla piaskowców mioceńskich (kolor pomarańczowy, zawartość illitu 10-20\%), prędkość zdecydowanie wzrasta w piaskowcach zbitych, skonsolidowanych charakteryzujących się niskimi porowatościami. Skały o najwyższej zawartości illitu - około $50 \%$ charakteryzują się najniższą porowatością efektywną. W przypadku skał o porowatości w zakresie 3-5\% możemy zauważyć, że fala $\mathrm{P}$ w piaskowcach rozchodzi się z prędkością $4500-5500 \mathrm{~m} / \mathrm{s}$, podczas gdy odpowiadające tym samym porowatościom mułowce charakteryzują się dużo niższą prędkością fali $\mathrm{P}$ - w zakresie $3400-3800 \mathrm{~m} / \mathrm{s}$.

\section{Wnioski}

Przeprowadzone badania zawartości poszczególnych minerałów ilastych pozwoliły na interpretację osadów miocenu autochtonicznego i wyznaczenie ciągłej krzywej zmian zawartości minerałów ilastych w profilu odwiertu R-1. todą spektrometrii

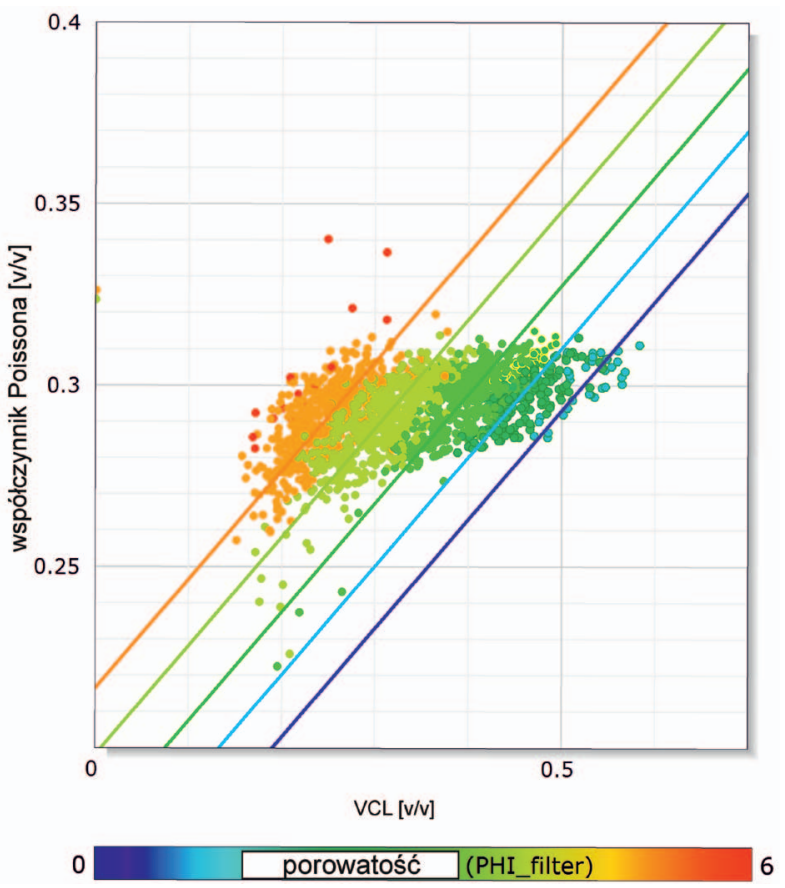

Rys. 11. Analiza wpływu zailenia na wartości współczynnika Poissona

Fig. 11. The analysis of the impact of shale volume on the values of the Poisson ratio
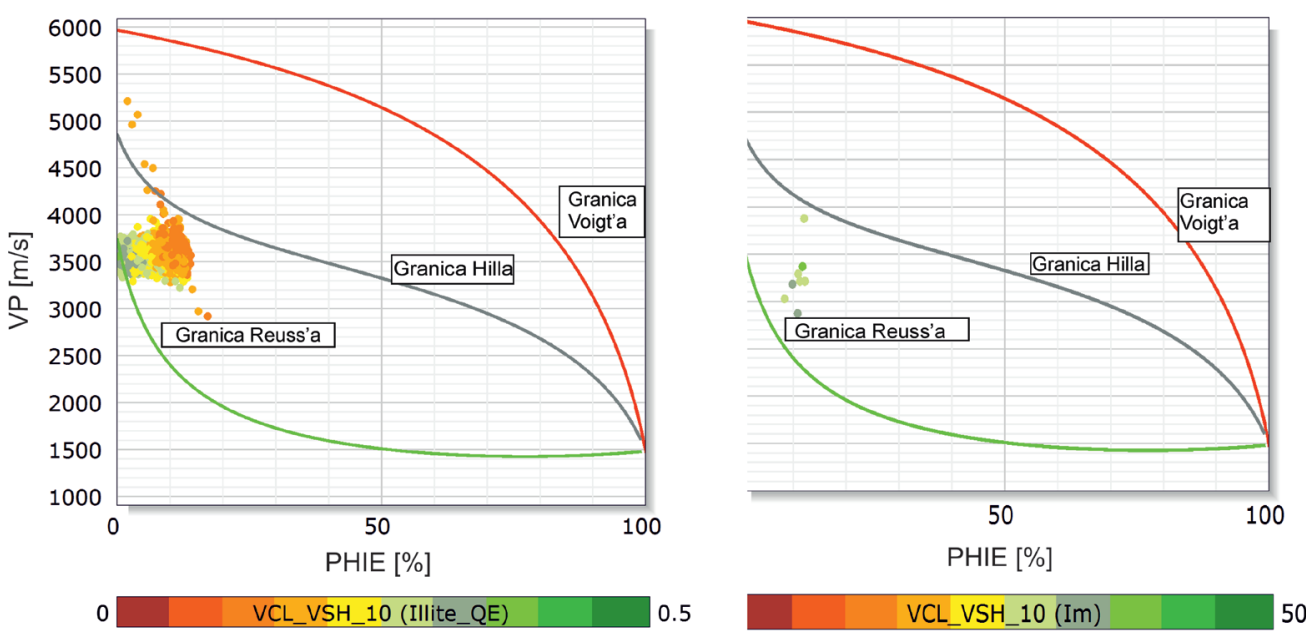

Rys. 12. Wykres krzyżowy prędkości fali P i porowatości na tle granic Voigta i Reussa. Po lewej analizy dla danych wyliczonych na podstawie geofizyki wiertniczej, kolorem oznaczono zawartość illitu, po prawej kolorem oznaczono zawartość illitu pomierzoną dla dziewięciu próbek me-

Fig. 12. Crossplot between $P$ wave velocity and porosity on the background of Voigt and Reuss bounds. On the left, the analysis of data calculated based on well logs, the color stands for illite volume in fraction, on the right illite content for the nine samples, measured by spectrometry

Pomierzone prędkości fal P i S oraz statyczne wartości parametrów sprężystych zostały przeliczone na podstawie zależności korelacyjnych do wartości dynamicznych. Przeanalizowano zmiany wartości parametrów sprężystych dla różnych zawartości minerałów ilastych.

Dynamiczne wartości prędkości fali S zmieniają się w granicach $1700-2500 \mathrm{~m} / \mathrm{s}$. Fala biegnie najszybciej w osadach o niskiej porowatości i niewielkim zaileniu, prędkość fali 
ulega spowolnieniu wraz ze wzrostem porowatości i zailenia. Wskazano także na zależność prędkości fali S od wartości modułu sprężystości objętościowej $(K)$ oraz wartości modułu Younga $(E)$ : im wyższe wartości modułów $K$ i $E$, tym wyższa prędkość fali S. Korelacje pomiędzy $V_{S}-K$ oraz $V_{S}-E$ wskazują na wprost proporcjonalne zależności dla stałych zakresów zawartości minerałów ilastych. Podobną zależność można zaobserwować w modelu Greenberga-Castagny dla utworów piaszczysto-ilastych. Wartości prędkości fal $\mathrm{P}$ i S pozostają w ścisłym związku z zawartością frakcji ilastej: obserwujemy wprost proporcjonalne zmiany prędkości fali P do prędkości fali S dla czterech wydzielonych zakresów zawartości iłów: 0-25\%, 25-50\%, 50-75\%, 75-100\%.

Widoczny jest także znaczny wpływ sumarycznej ilości minerałów ilastych zmieniających się w zakresie $15-60 \%$ na stosunek prędkości fali $\mathrm{P}$ do prędkości fali S. Stosunek prędkości fal $V_{p} / V_{s}$ dla czystych, nieporowatych piaskowców wynosi 1,75-1,8, natomiast w przypadku mułowców wartości $V_{p} / V_{s}$ wynoszą około 1,85-1,9. Wartości współczynnika Poissona $(v)$ wahają się w przedziale $0,22-0,32 v / v$, w interwałach o zbliżonej porowatości zaobserwować można wzrost wartości ze wzrostem zailenia.

Artykuł powstał na podstawie pracy statutowej pt.: Oznaczenie zawartości i rodzaju minerałów ilastych $w$ skałach klastycznych oraz analiza wpływu zailenia na prędkości propagacji fali $P$ i $S$ - praca INiG - PIB na zlecenie MNiSW; nr zlecenia 0098/ SG/2018, nr archiwalny DK-4100-0088/2018.

\section{Literatura}

Bała M., 2017. Charakterystyka parametrów sprężystych określonych na podstawie pomiarów geofizyki otworowej i modelowań teoretycznych w wybranych formacjach w otworach basenu bałtyckiego i wierconych na szelfie. Nafta-Gaz, 8: 558-570. DOI: 10.18668/NG. 2017.08.03.

Bowman T., 2010. Direct Method for Determining Organic Shale Potential from Porosity and Resistivity Logs to Identify Possible Resource Plays. Adapted from oral presentation at session, Genesis of Shale Gas - Physicochemical and Geochemical Constraints Affecting Methane Adsorption and Desorption. AAPG Annual Convention, New Orleans, LA.

Castagna J.P., Batzle M.L., Eastwood R.I., 1985. Relationships between compressional-wave and shear-wave velocities in clastic silicate rocks. Geophysics, 50: 571-581.

Castagna J.P., Batzle M., Kan T.K., 1993. Rock physics - The link between rock properties and AVO response. [W:] Castagna J.P., Backus M.M. (eds.). Offset-dependent reflectivity - Theory and practice of AVO analysis. SEG Investigations in Geophysics Series, 8: 135-171.

Katahara K.W., 1996. Clay mineral elastic properties. SEG Annual Meeting Expanded Technical Programme Abstracts, paper RP1.4.

Madejova J., Komadel P., 2001. Baseline studies of the clay minerals society source clays: infrared methods. Clays and Clay Minerals, 49(5): 410-432. DOI: 10.1346/CCMN.2001.0490508.

Marion D., Nur A., Han D., 1992. Compressional velocity and porosity in sand-clay mixtures. Geophysics, 52(4): 554-563.

Mavko G., Mukerji T., Dvorkin J., 2003. The Rock Physics Handbook. Tools for seismic analysis in Porous media. Cambridge University Press.

Mondol N.H., Jahren J., Bjorlykke K., 2008. Elastic properties of clay minerals. The Leading Edge, 27(6): 758-770. DOI: 10.1190/1.2944161.

Puskarczyk E., Krakowska P., Wawrzyniak-Guz K., Jarzyna J., 2017. Badania prędkości fal sprężystych i charakterystyka naprężeniowo-odkształceniowa w warunkach trójosiowego ściskania dla wybranych skał klastycznych i węglanowych. Zeszyty Naukowe Instytutu Gospodarki Surowcami Mineralnymi i Energia Polskiej Akademii Nauk, 101: 313-322.

Słota-Valim M., 2015. Static and dynamic elastic properties, the cause of the difference and conversion methods - case study. Nafta-Gaz, 11: 816-826. DOI: 10.18668/NG2015.11.02.

Wang Z., Wang H., Cates M.E., 2001. Effective elastic properties of solid clays. Geophysics, 66: 428-440.

Woeber A.F., Katz S., Ahrens T.J., 1963. Elasticity of selected rocks and minerals. Geophysics, 28: 658-663.

Zhu F., Gibson R.L., Estil R., 2001. A critical clay content model of Sand-Shale mixtures from $\log$ data in the Gulf of Thailand. SEG, Expanded Abstract: 1-5.

Zych I., Smółka-Gnutek P., 2014. Zastosowanie atrybutów sejsmicznych w konstrukcji modelu petrofizycznego na przykładzie mioceńskich utworów zapadliska przedkarpackiego. Przegląd Geologiczny, 62(12): 848-851.

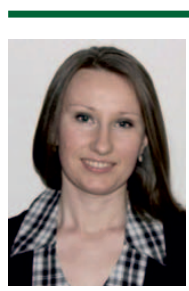

Mgr inż. Anita LIS-ŚLEDZIONA

Asystent w Zakładzie Geologii i Geochemii Instytut Nafty i Gazu - Państwowy Instytut Badawczy ul. Lubicz 25 A

31-503 Kraków

E-mail: anita.lis@inig.pl

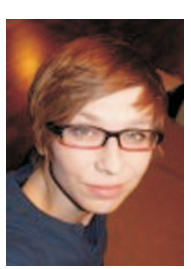

Dr inż. Maja MROCZKOWSKA-SZERSZEN

Adiunkt w Zakładzie Geologii i Geochemii

Instytut Nafty i Gazu - Państwowy Instytut Badawczy ul. Lubicz 25 A

31-503 Kraków

E-mail: mroczkowska@inig.pl 